\title{
Kinetics and Mechanism of the Aminolysis of Aryl Dithiocyclopentanecarboxylates in Acetonitrile
}

\author{
Kook Sun Jeong and Hyuck Keun Oh* \\ Department of Chemistry and Research Institute of Physics and Chemistry, Chonbuk National Lniversity \\ Chonju 561-756, Korea. E-mail: ohkeunachonbukac.kr \\ Received December 3, 2007
}

Key Words : Nucleophilic substitution. Aç̣l transfer reaction. Cross-interaction constant. Kinetic isotope effects. Stepwise mechanism

The two common mechanisms for the aminolysis of carbonyl. I, and thiocarbonyl. II, esters and carbonates are (i) concerted through a tetrahedral transition state (TS) and (ii) stepwise through a tetrahedral intermediate. ' The latter reaction pathway can be described by eq. (I), where $R$ and $L$ are nonleaving and leaving groups. and $\mathrm{N}$ represents an anine and $\mathrm{Y}$ is either $\mathrm{O}$ (I) or $\mathrm{S}$ (II). A nonlinear Bronsted

$$
\mathrm{N}+\mathrm{R}-\stackrel{\mathrm{Y}}{\mathrm{C}}-\mathrm{L} \underset{k_{\text {-a }}}{\stackrel{k_{\mathrm{a}}}{\rightleftharpoons}} \mathrm{R}-\underset{\substack{\mathrm{N}^{+} \\ \mathrm{T}}}{\stackrel{\mathrm{T}^{ \pm}}{\mathrm{Y}}} \stackrel{\mathrm{L}}{\stackrel{k_{\mathrm{b}}}{\longrightarrow}} \mathrm{R}-\underset{\underset{\mathrm{N}^{+}}{\mathrm{C}}}{\stackrel{\mathrm{Y}}{\mathrm{Y}}}+\mathrm{L}^{-}
$$

plot results from a change in the rate-determining step, from that of $k_{\mathrm{b}}$ at low amine basicity (with $\beta_{\text {nuc }} \geq 0.8$ ) to that of $k_{\mathrm{a}}$ at high anine basicity (with $\beta_{\text {nuc }} \leq 0.3$ ). Applying the steady-state condition to $\mathrm{T}^{ \pm}$in eq. (I), the equation $k_{\mathrm{N}}=k_{\mathrm{a}} k_{\mathrm{b}}$ $/\left(k_{-\mathrm{a}}+k_{\mathrm{b}}\right)=\left(k_{\mathrm{a}} / k_{-\mathrm{a}}\right) \times k_{\mathrm{b}}=K \cdot k_{\mathrm{b}}$ is obtained. and this accounts for the change in the rate-determining step at $\mathrm{p} K_{\mathrm{a}}{ }^{\circ}$ where $k_{-\mathrm{a}}$ $=k_{\mathrm{b}}$ applies. The aminolysis mechanisms naturally depend on $\mathrm{Y}, \mathrm{R}, \mathrm{L}, \mathrm{N}$ in eq. (l) and solvent. Fixing $\mathrm{L}\left(=\mathrm{SC}_{6} \mathrm{H}_{4} \mathrm{Z}\right)$ and solvent (acetonitrile), we recently found interesting mechanistic changeover due to changes in $\mathrm{Y}(\mathrm{O} \text { or } \mathrm{S})^{2}$. N (benzy lanines or anilines) ${ }^{2,3}$ and $\mathrm{R}\left(\mathrm{CH}_{3}, \mathrm{C}_{6} \mathrm{H}_{3} \mathrm{CH}_{2}, \mathrm{C}_{6} \mathrm{H}_{5}\right.$ or $\left.\mathrm{C}_{2} \mathrm{H}_{5} \mathrm{O}\right){ }^{25}$ For example. change of $\mathrm{Y}$ from $\mathrm{O}$ to $\mathrm{S}$ resulted in lowering of $\mathrm{pK}_{3}{ }^{\circ}$ for $\mathrm{R}=\mathrm{CH}_{3}$ and $\mathrm{C}_{6} \mathrm{H}_{5}$ so that the rateliniting step of the aninolysis for carbonyl esters. I. with benzylanines ${ }^{3 \mathrm{a}, \mathrm{b}}$ changed from expulsion of thiolate anion. ArS: from $\mathrm{T}^{ \pm}$(with $\beta_{\mathrm{uuc}}=\beta_{\mathrm{X}}=1.36$ and 1.86 , and $\rho_{\mathrm{Nz}}>0$ ) to formation of $\mathrm{T}^{ \pm}$(with $\beta_{\mathrm{X}}=0.55$ and 0.63 and $\rho_{\mathrm{Nz}}>0$ ) for thiocarbonyl esters, ${ }^{\hat{}{ }^{c . d} \mathrm{~d}}$ II. The aminolysis of all the carbonyl (I) series except for $\mathrm{R}=\mathrm{C}_{2} \mathrm{H}_{5} \mathrm{O}$ (concerted. with $\rho_{\mathrm{Nz}}<0$ ) proceeds through the stepwise path with rate-limiting expulsion of the leaving group (with $\beta_{\alpha}=1.36-2.11$ and $\rho_{\mathrm{NZ}}>0$ ).

Other criteria for this mechanistic change are the sign reversal of the cross-interaction constant. ${ }^{6} \rho \mathrm{Nz}$ in eqs. (2) where $X$ and $Z$ denote substituents in the nucleophile (amine) and leaving group respectively. from positive

$$
\begin{gathered}
\log \left(k_{\mathrm{X} Z} / k_{\mathrm{HH}}\right)=\rho_{\mathrm{X}} \sigma_{\mathrm{X}}+\rho_{\mathrm{Z}} \sigma_{\mathrm{Z}}+\rho_{\mathrm{XZ}} \sigma_{\mathrm{X}} \sigma_{\mathrm{Z}} \\
\rho_{\mathrm{XZ}}=\partial \rho_{\mathrm{X}} / \partial \sigma_{\mathrm{Z}}=\partial \rho_{\mathrm{Z}} / \partial \sigma_{\mathrm{X}}
\end{gathered}
$$

$\left(\rho_{\mathrm{Nz}}>0\right)$ to negative at $\mathrm{pK}_{\mathrm{a}}{ }^{\circ}$ as the amine basicity is increased. and from adherence to failure of the reactivityselectivity principle (RSP)

The aminolysis of dithio esters and carbonates. II. has been studied in aqueous and acetonitrile solutions." An important advantage of using acetonitrile medium is that there are no complications arising from a kinetically important proton transfer from $\mathrm{T}^{ \pm}$to the amine.

As an extension of our work on the aminolysis of dithio esters in acetonitrile. we now examine the reactions of anilines (ANs) with aryl dithiocyclopentanecarboxylates at $10.0^{\circ} \mathrm{C}$. eq. (3). We are interested in the effects of the acyl group. $\mathrm{R}$ and the amines on the mechanism, especially on the sign and magnitude of the cross-interaction constant, $\rho_{\mathrm{X} Z}$ in eqs. (2).

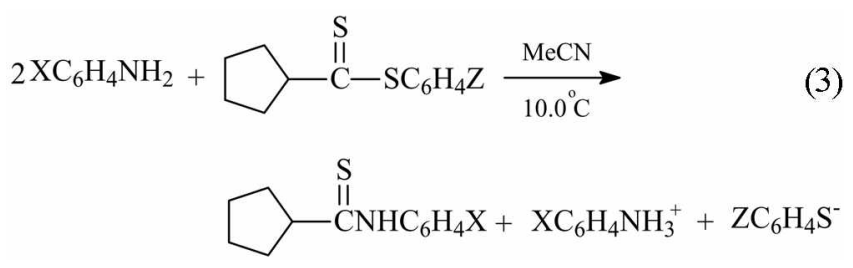

\section{Results and Discussion}

The reactions studied in this work followed the rate law described by eqs. (4) and (5). where $S$ and $N$ represent the substrate and nucleophile. aniline. and $k_{\mathrm{N}}$ is the rate constant for aminolysis of the substrate. The values of $k \mathrm{v}$ were

$$
\begin{aligned}
\text { Rate } & =k_{\text {ots }}[\mathrm{S}] \\
k_{\mathrm{obs}} & =k_{\mathrm{v}}[\mathrm{N}]
\end{aligned}
$$

obtained as the slopes of plots of $k_{\mathrm{obs}}$ against [N]. and are summarized in Tables 1 for aryl dithiocyclopentanecarboxylates. In Table 1. the selectivity parameters. $\rho_{\mathrm{x}}, \beta_{\mathrm{x}}, \rho_{\mathrm{z}}, \beta_{2}$ and $\rho_{\mathrm{X} z}$, are also shown. In the detenmination of Brōnsted coefficients. structurally similar amines are known to change in parallel with the $\mathrm{p} K_{4}\left(\mathrm{H}_{2} \mathrm{O}\right)$ values ${ }^{5 \mathrm{n} .7}$ so that the $\beta_{\mathrm{x}}\left(\beta_{\mathrm{nuc}}\right)$ values are considered reliable. Although the absolute $\beta_{2}$ values may not be reliable. the comparison of $\beta_{z}$ values for different series of substrates is justified since we have detemined the $\beta_{Z}$ values in the same reaction medium. acetonitrile. Relatively large magnitudes of $\rho_{\mathrm{X}}$ and $\rho_{Z}$ values for the aminolysis seems to support a stepwise mechanism 
Table 1. The Second Order Rate Constants, $k_{\mathrm{N}} \times 10^{3} \mathrm{~d}_{112^{3}} \mathrm{~mol}^{-1} \mathrm{~s}^{-1}$ for the Reactions of Z-Aryl Dithiocyclopentanecarbosylates with $\mathrm{X}$ Anilines in Acetonitrile at $10.0^{\circ} \mathrm{C}$

\begin{tabular}{|c|c|c|c|c|c|c|}
\hline \multirow{2}{*}{$X$} & \multicolumn{4}{|c|}{2} & \multirow{2}{*}{$\rho z^{a}$} & \multirow{2}{*}{$\beta_{\mathrm{z}}^{b}$} \\
\hline & $p-\mathrm{Me}$ & $\mathrm{H}$ & $p-\mathrm{Cl}$ & $p-\mathrm{Br}$ & & \\
\hline \multirow[t]{3}{*}{$p$-OMe } & $11.4^{\prime \prime}$ & 22.1 & 155 & 260 & $3.42 \pm 0.07$ & $-1.41 \pm 0.01$ \\
\hline & 7.78 & & & 182 & & \\
\hline & $5.36^{d}$ & & & 125 & & \\
\hline$p-\mathrm{Me}$ & 4.42 & 14.7 & 108 & 129 & $3.03 \pm 0.06$ & $-1.50 \pm 0.03$ \\
\hline $\mathrm{H}$ & 2.24 & 7.59 & 63.5 & 77.9 & $3.82 \pm 0.07$ & $-1.57 \pm 0.02$ \\
\hline$p-\mathrm{Cl}$ & 0.708 & 2.94 & 30.1 & 40.8 & $4.31 \pm 0.08$ & $-1.76 \pm 0.04$ \\
\hline \multirow[t]{3}{*}{$m-\mathrm{Cl}$} & 0.778 & 2.29 & 24.0 & 49.7 & $4.40 \pm 0.09$ & $-1.78 \pm 0.04$ \\
\hline & 0.537 & & & 34.8 & & \\
\hline & 0.365 & & & 240 & & \\
\hline$a^{e}$ & $-2.19 \pm 0.06$ & $-1.87 \pm 0.05$ & $-1.53 \pm 0.04$ & $-1.37 \pm 0.03$ & $\rho_{\mathrm{sz}}^{f}=$ & $1.87 \pm 0.07$ \\
\hline$\beta^{\circ}$ & $0.76 \pm 0.04$ & $0.65 \pm 0.02$ & $0.53 \pm 0.02$ & $0.47 \pm 0.02$ & & \\
\hline
\end{tabular}

"The $\sigma$ values were taken from C. Hansch. A. Leo, and R. W. Tatt. Chem. Rev. 1991, 91, 165. Correlation cefficients were better than 0.995 in all cases. ${ }^{3}$ The $\mathrm{pKa}$ values were taken from ed. J. Bukinghan. Dictionan' of Orgonic Chentism: Chapman and Hall. New: York 1982 . 5 th. ed. $Z=\mathrm{p}-\mathrm{Br}$ was excluded from the Bronsted plot for $\beta_{2}$ due to an unreliable pKa values. Correlation coefficients were better than 0.998 in all cases. ${ }^{\circ}$ At $20{ }^{\circ} \mathrm{C}$. "At 0.0 ${ }^{\mathrm{C}}$. "The source of $\sigma$ is the same as for footnote a. Correlation coefticients were better than 0.995 in all cases. ${ }^{\circ}$ Correlation coefficients was 0.996 . ${ }^{\text {g The }}$ pKa falues were taken from: hinoduction to Orgonic Chamstiy. A. Streitwiser. Jr and C. I. Heathcock Third Edition. 1989. p 693. Macmillan Publishing Co. New York. Correlation coefticients were better than 0.997 in all cases.

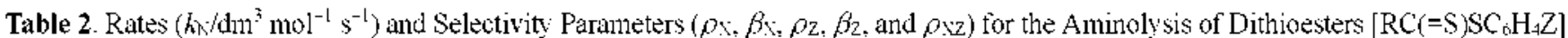
with Anilines $\left(\mathrm{XC}_{5} \mathrm{H}_{\Perp} \mathrm{NH}_{2}\right)$ in Acetonitrile

\begin{tabular}{|c|c|c|c|c|c|c|c|c|}
\hline Entry & $\mathrm{R}$ & $k_{\mathrm{N}}{ }^{\sigma}$ & $\rho^{b}$ & $\beta_{\lambda^{b}}^{b}$ & $\rho_{z}{ }^{\prime}$ & $\beta_{z}^{c}$ & $\rho: z^{d}$ & Ref. \\
\hline 1 & $\mathrm{CH}_{3}$ & $9.46 \times 10^{-4}\left(50.0^{\circ} \mathrm{C}\right)$ & -3.05 & 0.84 & 1.90 & -0.81 & 0.58 & $2 d$ \\
\hline 2 & Cyclopentyl & $7.59 \times 10^{-3}\left(10.0^{\circ} \mathrm{C}\right)$ & -1.87 & 0.65 & 3.82 & -1.57 & 1.87 & This work \\
\hline 3 & $\mathrm{C}_{6} \mathrm{H}_{5} \mathrm{CH}_{2}$ & $2.76 \times 10^{-1}\left(45.0^{\circ} \mathrm{C}\right)$ & -2.64 & 0.93 & 2.72 & -1.10 & 1.41 & $3 b$ \\
\hline 4 & $\mathrm{C}_{5} \mathrm{H}_{5}$ & $2.85 \times 10^{-3}\left(55.0^{\circ} \mathrm{C}\right)$ & -2.86 & 1.03 & 2.26 & -0.76 & 0.60 & $3 a$ \\
\hline 5 & $\mathrm{C}_{2} \mathrm{H}_{5} \mathrm{O}$ & $1.71 \times 10^{-2}\left(30.0^{\circ} \mathrm{C}\right)$ & -1.46 & 0.54 & 0.45 & -0.19 & -0.56 & $4 b$ \\
\hline
\end{tabular}

"For $X=Y=Z=H$. "for $Z=H$. "For $X=H$. "For $Y=H$ when $Y$ is varied.

with rate limiting expulsion of the aryl thiolate group. In order to facilitate comparisons of rates and selectivity parameters between different substrates, (for different $\mathrm{R}$ groups). we have sunmarized them in Table 2. First of all, the anilinolysis of $O$-ethyl $S$-aryl dithiocarbonates ${ }^{\text {tb }}(\mathrm{R}=$ $\mathrm{C}_{2} \mathrm{H}_{5} \mathrm{O}$ ) has been reported to proceed concertedly based on (i) small magnitude of $\beta_{\mathrm{X}}(=0.5)$ and $\beta_{\mathrm{Z}}(=-0.2)$ values relative to those reacting stepwise with large $\beta_{\alpha}(\geq 0.7)$ and $-\beta_{Z}(\leq-0.8)^{1.8}$ and (ii) negative $\rho_{\times Z}(<0){ }^{6 c}$ For the rest of Rs (entries 1-4), the same mechanism applies with positive $\rho_{\mathrm{NZ}}$. large magnitude of $\beta_{x}$ and $\beta_{Z}$, and adherence to the reactivity-selectivity principle (RSP). ${ }^{69}$ i.e. . rate-liniting expulsion of thiolate anion ( $\mathrm{ArS}^{-}$) leaving group from the tetrahedral intermediate, $\mathrm{T}^{ \pm}$. Reference to Table 2 reveals that the rate is the fastest ( $k_{N}$ is the greatest) with $\mathrm{R}=\mathrm{c}-\mathrm{C}_{\mathbf{s}} \mathrm{H}$ among the four stepwise reaction series (entries 1-4). Albeit exact comparison is difficult due to the $k$ values determined at different temperatures, approximate rate order is $\mathrm{R}=c-\mathrm{C}_{3} \mathrm{H}_{9}$ $\left(\sigma^{*}=-0.15\right)>\mathrm{CH}_{3}(0.0)>\mathrm{C}_{6} \mathrm{H}_{4} \mathrm{CH}_{2}(+0.22)>\mathrm{C}_{6} \mathrm{H}_{5}(+0.60)$ which is the order of decreasing electron donating ability of the $\mathrm{R}$ group represented by the Taft $\sigma^{*}$ scale $e^{10}$ as shown in the parenthesis. This is quite reasonable in view of the ratelimiting expulsion of $\mathrm{ArS}^{-}$group from $\mathrm{T}^{=}$, since in the tetrahedral structure only the inductive effect is expected to apply and the greater the electron donation by $\mathrm{R}$. the greater will be the leaving ability of $\mathrm{ArS}^{-}$group $\left(k_{\mathrm{b}}\right)$. If the electronic effect of $\mathrm{R}$ were predominant in the bond formation step $\left(k_{\mathrm{a}}\right)$. then the rate sequence should have been in the reverse order since a stronger electron acceptor $\mathrm{R}$ will lead to a stronger positive clarge on the carbonyl carbon in the substrate.

An important aspect we note in Tables 2 is that the magnitude of $\rho_{\mathrm{xz}}$ is unusually large $\left(\rho_{\mathrm{xz}}=1.87\right)$ for $\mathrm{R}=\mathrm{c}-$ $\mathrm{C}_{5} \mathrm{H}_{y}$ (entry 2). The size of $\rho_{\mathrm{X} z}$ is considered to represent the intensity of interaction in the $\mathrm{TS}^{6}$ between the two substituents in the nucleophile $(X)$ and leaving group $(Z)$. and hence the larger the $\rho \mathrm{XZ}$, the stronger is the interaction. i.e. the closer is the two fragments. the nucleophile and leaving group. in the TS.

The kinetic isotope effects involving deuterated amine nucleophile $\left(\mathrm{XC}_{6} \mathrm{H}_{4} \mathrm{ND}_{2}\right) . k_{\mathrm{H}} / k_{\mathrm{D}}$, have been deternined ${ }^{6 t}$ in acetonitrile as shown in Table 3 . We note that the $k_{\mathrm{H}} / k_{\mathrm{D}}$ values are significantly greater than unity so that constitute primary kinetic isotope effects. The amine proton shift is implicated by these greater than unity $k_{\mathrm{H}} / k_{\mathrm{D}}$ values. ${ }^{6}$ Thus we propose that deprotonation of an amine hydrogen takes place concurrently with the expulsion of the thiophenolate anion, $k_{b}$, as shown in Scheme 1 . In the proposed TS structure. the leaving group departure is assisted by partial protonation and therefore the difficulty in forming $\mathrm{C}=\mathrm{S}$ bond may be partially alleviated. This could explain the relatively insignificant effect of substitution of $\mathrm{S}^{-}$for $\mathrm{O}^{-}$discussed. Since the positive $\rho_{\mathrm{Xz}}$ should require a greater degree of leaving group departure $\left(\delta \rho_{Z}>0\right)$ and a greater degree of 
Table 3. The Secondary Kinetic Isotope Effects for the Reactions of Z-Aryl Dithiocyclopentanecarboxylates with Deuterated XAnilines in Acetonituile at $10.0^{\circ} \mathrm{C}$

\begin{tabular}{lcccc}
\hline $\mathrm{X}$ & $Z$ & $k_{\mathrm{H}} \times 10^{3}\left(\mathrm{M}^{-1} \mathrm{~s}^{-1}\right)$ & $k_{\mathrm{D}} \times 10^{2}\left(\mathrm{M}^{-1} \mathrm{~s}^{-1}\right)$ & $k_{\mathrm{H}} / k_{\mathrm{L}}$ \\
\hline$p-\mathrm{OMe}$ & $p-\mathrm{Me}$ & $7.78( \pm 0.05)$ & $4.52( \pm 0.04)$ & $1.72 \pm 0.02^{\sigma}$ \\
$p-\mathrm{OMe}$ & $\mathrm{H}$ & $22.1( \pm 0.30)$ & $13.8( \pm 0.12)$ & $1.60 \pm 0.02$ \\
$p-\mathrm{OMe}$ & $p-\mathrm{Cl}$ & $155( \pm 4.00)$ & $106( \pm 2.55)$ & $1.45 \pm 0.04$ \\
$P-\mathrm{OMe}$ & $p-\mathrm{Br}$ & $182( \pm 4.80)$ & $142( \pm 3.25)$ & $1.28 \pm 0.03$ \\
$p-\mathrm{Cl}$ & $p-\mathrm{Me}$ & $0.708( \pm 0.01)$ & $0.418( \pm 0.008)$ & $1.69 \pm 0.02$ \\
$p-\mathrm{Cl}$ & $\mathrm{H}$ & $2.94( \pm 0.04)$ & $1.89( \pm 0.03)$ & $1.53 \pm 0.03$ \\
$p-\mathrm{Cl}$ & $p-\mathrm{Cl}$ & $30.1( \pm 0.60)$ & $21.8( \pm 0.55)$ & $1.38 \pm 0.03$ \\
$p-\mathrm{Cl}$ & $p-\mathrm{Br}$ & $40.8( \pm 0.75)$ & $32.6( \pm 0.65)$ & $1.25 \pm 0.02$ \\
\hline${ }^{2}$
\end{tabular}

"Standard deviations.

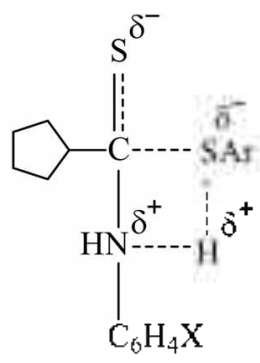

Scheme 1

bond formation $\left(\delta \rho_{\mathrm{X}}>0 \rightarrow \delta \rho_{\mathrm{X}}<0\right)$ with a weaker nucelophile $\left(\delta \sigma_{\mathrm{X}}>0\right)$ and nucleofuge $\left(\delta \sigma_{\mathrm{z}}<0\right)$ respectively in accordance with aryl phenyldithioacetate, ${ }^{6}$ larger $k_{\mathrm{H}} / k_{\mathrm{D}}$ values i.e., greater degree of proton transfer with $\mathrm{X}=p-\mathrm{Cl}$ than with $\mathrm{X}=p-\mathrm{OMe}$, and with $Z=p$-Me than with $Z=p-\mathrm{Br}$ (or $Z=p-\mathrm{Cl}$ ). are consistent with the expected trends in both cases (Table 3) ${ }^{6 b}$ Alternatively. proton transfer can occur from the $\mathrm{NH}^{+}$to an anionic (thiocarbonyl) sulfur atom. which could still be rate-liniting since the neutral intermediate should breakdown rapidly to give a tautomer of the ultimate thioamide product. ${ }^{*}$

This interpretation based on the proposed TS structure is also supported by the activation parameters in Table 4 . The relatively low activation enthalpies. $\Delta H^{x}$. and relatively large negative activation entropies. $\Delta S^{t}$, are in line with the concurrent proton transfer and leaving group expulsion in the TS. Since the leaving group expulsion and $\mathrm{C}=\mathrm{S}$ bond formation are partly assisted by the proton transfer. the reaction (or the TS formation) can be a low energy' $\left(\Delta H^{x}=\right.$ $\sim 5 \mathrm{kcal} \cdot \mathrm{mol}^{-1}$ ) but highly structured (large negative $\Delta S^{x}=$

Table 4. Activation Parameters ${ }^{2}$ tor the Reactions of Z-Arvl Dithiocyclopentanecarbosylates with X-Anilines in Acetonitrile

\begin{tabular}{lccc}
\hline $\mathrm{X}$ & 2 & $\Delta H^{*} / \mathrm{kcal} \mathrm{mol}^{-1}$ & $-\Delta S^{*} / \mathrm{cal} \mathrm{mol}^{-1} \mathrm{~K}^{-1}$ \\
\hline$p$-OMe & $p-\mathrm{Me}$ & 5.5 & 49 \\
$p-\mathrm{OMe}$ & $p-\mathrm{Br}$ & 5.1 & 44 \\
$p-\mathrm{Cl}$ & $p-\mathrm{Me}$ & 5.4 & 54 \\
$p-\mathrm{Cl}$ & $p-\mathrm{Br}$ & 5.1 & 47 \\
\hline
\end{tabular}

"Calculated by the Evring equation. The maximum errors calculated (by the method of K. B. Wiberg. Physical Organic Chemistry, Wiley New York 1964. p 378.) are $=0.5 \mathrm{kcal} \mathrm{mol} \mathrm{l}^{-1}$ and $=2 \mathrm{e.tl}$. for $\Delta H^{x}$ and $\Delta S^{x}$. respectively.
$-44 \sim-50$ e.u) process. The $\Delta H^{x}$ values are rather low but similar values are also reported for the uncatalyzed aminolysis reactions of $\mathrm{CF}_{3} \mathrm{CO}_{2} \mathrm{C}_{6} \mathrm{H}_{4} \mathrm{NO}_{2}\left(\Delta H^{x}=2.6 \mathrm{kcal} \mathrm{mol}^{-1}\right.$, $\Delta S^{x}=-46$ e.u. $)^{11}$ and 2.4-dinitrophenyl benzoates $\left(\Delta H^{x}=2.3\right.$ $\mathrm{kcal} \mathrm{mol}{ }^{-1}, \Delta S^{ \pm}=-44$ e.u. $) .{ }^{12}$ The insensitivity of $\Delta H^{x}$ values to the substituents in the amine and leaving group could result from the complex $k_{\mathrm{v}}\left(k_{\mathrm{a}} / k_{-\mathrm{a}} \cdot k_{\mathrm{b}}\right)$ values since the effects of substituents on $k_{a,} k_{\text {-a }}$ and $\mathrm{k}_{\mathrm{b}}$ may compensate each other.

In summary. the aminoly sis of Z-aryl dithiocyclopentanecarboxylates with $X$-anilines proceeds by a stepwise mechanism with rate-limiting expulsion of the leaving group, $\mathrm{ArS}^{-}$, from a tetrahedral intermediate. $\mathrm{T}^{ \pm}$. This prediction is based on faster rates for dithio (II) than for thiol (I) esters, the large selectivity parameters, $\beta_{\mathrm{S}} \beta_{\mathrm{Z}}$ and $\rho_{\mathrm{Xz}}$, and adherence to the reactivity-selectivity principle (RSP). The kinetic isotope effects involving deuterated aniline nucleophiles $\left(\mathrm{XC}_{6} \mathrm{H}_{4} \mathrm{ND}_{2}\right) . k_{\mathrm{H}} / k_{\mathrm{D}} \equiv 1.3-1.7$. and low $\Delta H^{z}$ and large negative $\Delta S^{t x}$ values suggest that proton transfer occurs concurrently with the leaving group departure in a fourcenter type transition state.

\section{Experimental Section}

Materials. Merck GR acetonitrile was used after three distillations. The benzylamine nucleophiles. Aldrich GR, were used without further purification. Thiophenols and cyclopentanecarbonyl chloride were Tokyo Kasei GR grade.

Preparartions of Thiophenyl Cyclopentanecarboxylates. Thiophenol derivatives and cyclopentanecarbonyl clloride were dissolved in anhydrous ether and added pyridine carefully keeping temperature to $0-5^{\circ} \mathrm{C}$. Ice was then added to the reaction mixture and ether layer was separated, dried on $\mathrm{MgSO}_{4}$ and distilled under reduced pressure to remove solvent. IR (Nicolet 5BX FT-IR) and ${ }^{1} \mathrm{H}$ and ${ }^{13} \mathrm{C}$ NMR (JEOL $400 \mathrm{MHz}$ ) data are as follows:

$p$-Thiotolyl cyclopentanecarboxylate: Liquid, $\mathrm{IR}(\mathrm{KBr})$, 2959 (C.H. aromatic), 2932 (C.H. CH$\left.{ }_{3}\right), 1703$ (C=O), 1609 $\left(\mathrm{C}=\mathrm{C}\right.$. aromatic). 817 (C-S): ${ }^{1} \mathrm{H}$ NMR $\left(400 \mathrm{MHz}, \mathrm{CDCl}_{3}\right)$, $1.40-2.13\left(8 \mathrm{H}, \mathrm{m} . \mathrm{CH}_{2}\right) .2 .38\left(3 \mathrm{H} . \mathrm{s}, \mathrm{CH}_{2}\right) .2 .40-2.46(\mathrm{lH}$, m. CH), 7.24 (2H. d. $J=8.30 \mathrm{MHz}$, meta H), $7.3 \mathrm{l}(2 \mathrm{H} . \mathrm{d}, J$ $=8.30 \mathrm{MHz}$, ortho $\mathrm{H}):{ }^{13} \mathrm{C}$ NMR $\left(100.4 \mathrm{MHz} . \mathrm{CDCl}_{3}\right)$, $201.3(\mathrm{C}=\mathrm{O}), 139.3,134.4,129.9 .124 .6,52.8,30.6,25.9$. 21.1. Mass. $m z 220\left(\mathrm{M}^{+}\right)$. Anal. Calcd. for $\mathrm{C}_{13} \mathrm{H}_{16} \mathrm{OS}: \mathrm{C}$, $70.8 ; \mathrm{H}, 7.32$. Found: $\mathrm{C}, 70.6 ; \mathrm{H}, 7.34$.

Thiophenyl cyclopentanecarboxylate: Liquid. IR ( $\mathrm{KBr}$ ). 2958 (C-H. aromatic), $1705(\mathrm{C}=\mathrm{O}), 1473(\mathrm{C}=\mathrm{C}$. aromatic). 809 (C-S): ${ }^{1} \mathrm{H}$ NMR (400 MHz, CDCl 3$) .1 .36-1.99(8 \mathrm{H}, \mathrm{m}$, $\left.\mathrm{CH}_{2}\right) \cdot 2.35-2.45(\mathrm{lH}, \mathrm{m} . \mathrm{CH}) .7 .26(2 \mathrm{H}$. d. $J=7.81 \mathrm{MHz}$. meta H), $7.30(2 \mathrm{H}$. d, $J=7.81 \mathrm{MHz}$, ortho $\mathrm{H}) ;{ }^{13} \mathrm{C}$ NMR $\left(100.4 \mathrm{MHz}, \mathrm{CDCl}_{3}\right) .200 .6(\mathrm{C}=\mathrm{O}), 134.3,129.0,128.9$. 128.1, 52.8. 30.5. 25.8; Mass. $m z 206\left(\mathrm{M}^{-}\right)$. Anal. Calcd. for $\mathrm{C}_{12} \mathrm{H}_{14} \mathrm{OS}: \mathrm{C}, 69.8 ; \mathrm{H}, 6.84$. Found: $\mathrm{C}, 70.1 ; \mathrm{H} .6 .86$.

p-Chlorothiophenyl cyclopentanecarboxylate: Liquid, IR $(\mathrm{KBr}) .2957$ (C-H. aromatic). $1703(\mathrm{C}=\mathrm{O}), 1498(\mathrm{C}=\mathrm{C}$. aromatic), 806 (C-S): ${ }^{1} \mathrm{H}$ NMR (400 $\mathrm{MHz}, \mathrm{CDCl}_{3}$ ). 1.53$2.00\left(8 \mathrm{H} . \mathrm{m}, \mathrm{CH}_{2}\right), 2.25-2.34$ (IH. m, CH), 7.31 (2H. d, $J=$ $8.78 \mathrm{MH} \measuredangle$, meta H), $7.35(2 \mathrm{H} . \mathrm{d} . J=8.78 \mathrm{MH} \measuredangle$, ortho $\mathrm{H}),{ }^{13} \mathrm{C}$ 
NMR $\left(100.4 \mathrm{MHz}, \mathrm{CDCl}_{3}\right), 200.3(\mathrm{C}=\mathrm{O}) .135 .7 .135 .5 .129 .3$. 126.5. 53.0, 30.5. 25.8; Mass. $m z 240\left(\mathrm{M}^{+}\right)$. Anal. Calcd. for $\mathrm{C}_{1}: \mathrm{H}_{13} \mathrm{ClOS}: \mathrm{C} .59 .8 ; \mathrm{H}, 5.44$. Found: $\mathrm{C}, 60.1 ; \mathrm{H}, 5.46$.

p-Bromothiophenyl cyclopentanecarboxylate: Liquid. IR (KBr). 2957 (C-H. aronatic), $1707(\mathrm{C}=\mathrm{O}) .1498(\mathrm{C}=\mathrm{C}$. aromatic), 812 (C-S); ${ }^{1} \mathrm{H}$ NMR $\left(400 \mathrm{MHz}, \mathrm{CDCl}_{3}\right), 1.38-$ $2.16\left(8 \mathrm{H}\right.$. m. $\left.\mathrm{CH}_{2}\right), 2.25-2.34(\mathrm{lH}, \mathrm{m} . \mathrm{CH}), 7.24(2 \mathrm{H}, \mathrm{d} . J=$ $8.78 \mathrm{MHz}$. meta H), $7.50(2 \mathrm{H}, \mathrm{d} . J=8.78 \mathrm{MHz}$, ortho $\mathrm{H}):{ }^{13} \mathrm{C}$ NMR ( $\left.100.4 \mathrm{MHz}, \mathrm{CDCl}_{3}\right), 200 . \mathrm{I}(\mathrm{C}=\mathrm{O})$. 135.9. 132.2. 127.2. 123.7. 53.0, 30.5. 25.8; Mass. $m z 283\left(\mathrm{M}^{+}\right)$. Anal. Calcd. for $\mathrm{C}_{1}: \mathrm{H}_{13} \mathrm{BrOS}$ : C. $50.5 ; \mathrm{H}, 4.59$. Found: C. 50.7; H. 4.57 .

Preparartions of phenyl dithiocyclopentanecarboxylates. The thiophenyl cyclopentanecarbosylates prepared as above were dissolved in dry toluene and refluxed with Lawesson's reagent (Aldrich G R. grade). After extraction of the reaction mixture with dichloromethane, dried and removed solvent by distillation under reduced pressure. Separation by column chromatography gave the products. for which the following analytical data were obtained.

p-Tolyl dithiocyclopentanecarboxylate: Liquid. IR $(\mathrm{KBr}), 2975\left(\mathrm{C} \cdot \mathrm{H}\right.$. aromatic), $2933\left(\mathrm{C} \cdot \mathrm{H} . \mathrm{CH}_{3}\right), 1705(\mathrm{C}=\mathrm{S})$. 1499. $1487\left(\mathrm{C}=\mathrm{C}\right.$, aromatic): ${ }^{1} \mathrm{H}$ NMR $\left(400 \mathrm{MHz} . \mathrm{CDCl}_{3}\right)$. 1.33-2.03 $\left(8 \mathrm{H}, \mathrm{m}, \mathrm{CH}_{-}\right) .2 .30\left(3 \mathrm{H} . \mathrm{s} . \mathrm{CH}_{3}\right) .2 .4 \mathrm{l}(\mathrm{lH} . \mathrm{m}$. $\mathrm{CH})$. 7.15-7.32 $\left(4 \mathrm{H}, \mathrm{m}\right.$, aromatic ring): ${ }^{13} \mathrm{C}$ NMR $(100.4$ $\left.\mathrm{MHz} . \mathrm{CDCl}_{3}\right), 200.7(\mathrm{C}=\mathrm{S}) .134 .4 .133 .4,129.8 .129 .5$. $52.7,30.5 .25 .8 .21 .1$. Mass, $m: z 252\left(\mathrm{M}^{+}\right)$. Anal. Calcd for $\mathrm{C}_{13} \mathrm{H}_{16} \mathrm{OS}_{2}: \mathrm{C}, 61.8 ; \mathrm{H}, 6.39$. Found: C, 62.0; H. 6.41.

Phenyl dithiocyclopentanecarboxylate: Liquid, $\mathrm{IR}(\mathrm{KBr})$. $2978(\mathrm{C}-\mathrm{H}$, aromatic). $1707(\mathrm{C}=\mathrm{S}), 1501.1488(\mathrm{C}=\mathrm{C}$. aromatic): ${ }^{1} \mathrm{H}$ NMR $\left(400 \mathrm{MHz}, \mathrm{CDCl}_{3}\right) .1 .38-2.02(8 \mathrm{H}, \mathrm{m}$. $\left.\mathrm{CH}_{2}\right) .2 .43(1 \mathrm{H}, \mathrm{m}, \mathrm{CH}), 7.29-7.35(5 \mathrm{H}$. m. aromatic ring): ${ }^{13} \mathrm{C} \mathrm{NMR}\left(100.4 \mathrm{MHz} . \mathrm{CDCl}_{3}\right) .200 .8(\mathrm{C}=\mathrm{S}), 134.4,129.1$. 129.0. 128.1, 52.8, 30.5, 25.8. Mass, $m z 222\left(\mathrm{M}^{-}\right)$. Anal. Calcd. for $\mathrm{C}_{1} \mathrm{H}_{14} \mathrm{~S}: \mathrm{C}, 64.8 ; \mathrm{H}, 6.35$. Found: $\mathrm{C} .64 .6 ; \mathrm{H} .6 .37$. p-Chlorophenyl dithiocyclopentanecarboxylate: Liquid. IR (KBr). 2982 (C-H. aromatic). 1711 (C=S), 1502. 1491 $\left(\mathrm{C}=\mathrm{C}\right.$, aromatic); ${ }^{1} \mathrm{H}$ NMR $\left(400 \mathrm{MHz}, \mathrm{CDCl}_{3}\right), 1.34-1.99$ $\left(8 \mathrm{H}, \mathrm{m} . \mathrm{CH}_{2}\right), 2.45(1 \mathrm{H}, \mathrm{m} . \mathrm{CH}), 7.21-7.29(4 \mathrm{H}, \mathrm{m}$, aromatic ring): ${ }^{13} \mathrm{C} \mathrm{NMR}\left(100.4 \mathrm{MHz}, \mathrm{CDCl}_{3}\right) .200 .1(\mathrm{C}=\mathrm{S}) .135 .6$. 135.3. 129.1 126.5, 52.8, 30.4 25.8. Mass. $m=256\left(\mathrm{M}^{+}\right)$. Anal. Calcd. for $\mathrm{C}_{12} \mathrm{H}_{13} \mathrm{ClS}_{2}: \mathrm{C}$. 56.1; H, 5.10. Found: C. 56.3: H. 5.12

p-Bromophenyl dithiocyclopentanecarboxylate: Liquid. IR $(\mathrm{KBr}) .2981(\mathrm{C}-\mathrm{H}$. aromatic). $1707(\mathrm{C}=\mathrm{S}) .1502 .1490$ $\left(\mathrm{C}=\mathrm{C}\right.$, aromatic): ${ }^{1} \mathrm{H}$ NMR $\left(400 \mathrm{MHz}, \mathrm{CDCl}_{\dot{3}}\right), \quad 1.36-2.05$ $\left(8 \mathrm{H}, \mathrm{m} . \mathrm{CH}_{2}\right), 2.44(1 \mathrm{H}, \mathrm{m} . \mathrm{CH}), 7.07 .7 .59(4 \mathrm{H}, \mathrm{m}$, aromatic ring): ${ }^{13} \mathrm{C} \mathrm{NMR}\left(100.4 \mathrm{MHz}, \mathrm{CDCl}_{3}\right) .200 .0(\mathrm{C}=\mathrm{S}) .135 .8$. 132.1. 127.2, 123.6, 52.9, 30.5, 25.8. Mass. $m z 299\left(\mathrm{M}^{+}\right)$. Anal. Calcd. for $\mathrm{C}_{13} \mathrm{H}_{13} \mathrm{BrS}_{2}: \mathrm{C}, 47.8: \mathrm{H} .4 .35$. Found: $\mathrm{C}$. 47.9: H. 4.37

Kinetic Measurement. Rates were measured conductometrically at $10.0 \pm 0.05^{\circ} \mathrm{C}$. The conductivity bridge used in this work was a self-nade computer automatic $A / D$ converter conductivity bridge. Pseudo-first-order rate constants. $k_{\text {obs. }}$ were deternined by the Guggenheim method ${ }^{13}$ with large excess of aniline. Second-order rate constants. $k \mathrm{v}$. were obtained from the slope of a plot of $k_{\mathrm{obs}} v$. aniline with more than five concentrations of more than three runs and were reproducible to within $\pm 3 \%$.

Product Analysis. Substrate. phenyl dithiocyclopentanecarboxylate $(0.05 \mathrm{~mole})$ was reacted with excess aniline $(0.5$ mole) with stirring for more than 15 half-lives at $10.0^{\circ} \mathrm{C}$ in acetonitrile, and the products were isolated by evapolating the solvent under reduced pressure. The product mixture was treated with colunn chromatography (silica gel, $20 \%$ ethylacetate-7/-hexane). Analysis of the product gave the following results.

Cyclopentyl-C(=S)NHC $\mathrm{NH}_{6}-\mathrm{OCH}_{3}$ : liquid, IR ( $\left.\mathrm{KBr}\right)$. $3448(\mathrm{~N}-\mathrm{H}), 2943\left(\mathrm{C} \cdot \mathrm{H} . \mathrm{CH}_{3}\right), 1707(\mathrm{C}=\mathrm{S}) .1535(\mathrm{C}=\mathrm{C}$. aromatic); ${ }^{1} \mathrm{H}$ NMR $\left(400 \mathrm{MHz} . \mathrm{CDCl}_{3}\right) .1 .34-2.05(8 \mathrm{H} . \mathrm{m}$, $\left.\mathrm{CH}_{2}\right) .2 .45(\mathrm{lH} . \mathrm{m} . \mathrm{CH}) .3 .7 \mathrm{l}$ (3H. s. $\left.\mathrm{CH}_{3}\right) .7 .08-7.60(4 \mathrm{H}$, m. aromatic ring): ${ }^{13} \mathrm{C}$ NMR $\left(100.4 \mathrm{MHz}, \mathrm{CDCl}_{3}\right), 200.1$ $(\mathrm{C}=\mathrm{S}), 135.9,132.2 .127 .2 .123 .7 .56 .9,52.9,30.5 .25 .8$ Mass, $m \geq 235\left(\mathrm{M}^{-}\right)$. Anal. Calcd. for $\mathrm{C}_{13} \mathrm{H}_{17} \mathrm{NOS}$ : C, 66.3 : H, 7.28. Found: C, 66.5; H, 7.26 .

Acknowledgements. This paper was supported by research funds of Chonbuk National University in 2007.

\section{References}

1. (a) Page. M. I.: Williams. A. Organtic and Bionorganic Mechanisnts: Longmant: Harlow. 1997. (b) Williams. A. Concented Organic and Bio-organic Mechanisms: CRC. Press: Boca Raton. 2000.

2. (a) Lee, I.: Koh, H. J. New J. Chem. 1996, 20, 131 . (b) Oh. H. K. Yang. J. H.: Lee. H. W.: Lee. I. Bull Korean Chem. Soc. 1999, 20. 1418. (c) Oh. H. K.: Shin. C. H.: Lee. I. Bull. Koream Chem. Soc. 1995. 16.657. (d) Oh. H. K.: Woo. S. Y.: Shin1. C. H.: Park. Y. S.: Lee. I. J. Org. Chent 1997.62.5780.

3. (a) Oh. H. K.: Shin, C. H. Lee, I. J. Chem. Soc, Perkin Trans. 2 1995. 1169. (b) Oh. H. K: Kim. S. K.: Lee, H. W.: Lee, I. J. Chem Soc. Perkin Trans. 2 2001. 1753

4. (a) Oh. H. K.: Lee. Y. H.: Lee. I. Int. J. Chem. Kinet. 2000.32. 131. (b) Oh. H. K.: Lee. J. Y.: Yun. T. H.: Park. Y. S.: Lee. I. Int. J. Chent. Kinet 1998, 30.419.

5. (a) Oh, H. K. Yang. J. H.: Cho, I. H.; Lee. H. W.: Lee. I. $h$ ht $d$. Chem Kinet. 2000. 32. 485. (b) Oh, H. K.: Kim. S. K.; Lee. I. Bull. Korean Chem. Soc. 1999. 20. 1017. (c) Oh. H. K. Kim. S. K.: Lee. H. W.: Lee. I. New J. Chem. 2001. 25.313. (d) Oh. H. K.: Kim. S. K.: Cho. I. H.: Lee. H. W.: Lee. I. J. Chent Soc., Perkin Trams. 22000.2306.

6. (a) Lee. I. Ad. Phus. Org. Chem. 1992, 27. 57. (b) Lee. I. Chem. Soc. Rev 1994, 24. 223. (c) Lee, I; Lee, H. W. Coll. Czech. Chem. Conmun 1999. 64. 1529. (d) Isaacs, N. S. Phusical Organic Chentistry. 2nd ed.: Longman: Essex: 1995: Chapter 4

7. (a) Lee. I.: Kim. C. K.: Hant. I. S.: Lee. H. W.: Kim. W. K.: Kim. Y. B. J. Phys Chent B 1999. 103. 7302. (b) Spillane. W. T.: Hogan1. G.; McGroth. P.: King. J.; Brack, C. J. Chem. Soc. Perkin Trans. 2 1996. 2099

8. Gresser. M. J. Jenck. W. P. J. Am. Chem Soc. 1977, $99.6963,6970$

9. (a) Pross. A. Adt: Phis. Org. Chen 1997. 14.69. (b) Buncel. E.: Wilson. H. J. Chem. Educ. 1987. 64. 475.

10. (a) Taft. R. W. In Steric Effects in Organic Chemistry: Newman. M. S.. Ed.; Wiley: New York. 1956. (b) Ruff. F.; Csizmadia. I. G. Organic Reactions. Equilibria. Kinetics and Hechanism: Elsevier: Amsterdam. 1994; p 191

11. Neuvonen. H. J. Chen. Soc. Perkin Trans. 2 1995. 951.

12. Castro. E. A.: Santander. C. L. J. Org Chent 1985.50.3595.

13. (a) Guggenheim. E. A. Phil. Mag. 1926. 2. 538 (b) Jeong. K. S.: Oh. H. K. Bull. Korean Chem. Soc. 2007, 28, 485. (c) Oh. H. K. Oh. J. Y. Bull Koram Chem Soc. 2006. 27. 143. (d) Oh. H. K. Ku. M. H.: Lee, H. W. Bull. Korean Chem. Soc. 2005, 26,935. 